\title{
Image of India and Pakistan in Digital Age: A Comparative Study on Tweets of International News Agencies
}

\author{
Dr. Muhammad Riaz Raza \\ Assistant Professor \\ Bahria University, Islamabad \\ mriaz.buic@bahria.edu.pk \\ Dr. Syed Abdul Siraj \\ Senior Professor \\ Bahria University, Islamabad \\ Muhammad Usman Saeed \\ Ph.D. Scholar \\ University of Central Punjab, Lahore
}

\begin{abstract}
Pakistan and India are two important South Asian neighboring countries equipped with nuclear capabilities. Unfortunately, the checkered bilateral foreign relations history is hostile and both countries have been fought four conventional wars since 1947. Mass media plays a significant role in shaping international relations and it is considered important to study the image of nations and states to assess international standing of a nation. In present study, we explored and compare the image of Pakistan and India in the representation of tweets of international news agencies. Methodologically, we used content analysis and network analysis techniques to find out the country-issue networks in news tweets. We have designated tweets of four major news agencies; Reuters, Agence France Press, Associated Press and Xinhua related to Pakistan and India for the duration of 7 years (from 2010-2016). We found that India and Pakistan are being covered negatively in news tweets of these news agencies. However, Pakistan's image seems more negative through lens of international news agencies as compare to India in terms of peace and conflict issues coverage. Both countries should take steps and formulate vibrant policy towards creation and dissemination of their positive image on digital media.
\end{abstract}

Keywords: Image theory, India image, Pakistan Image, news tweets, international news agencies, social network analysis.

\section{Introduction}

In this age of information and communication, digital media considered an alternative arena for international relations and nation image building across national to nation as well as people to people. The increasing importance of the digital image building and dissemination power of cyber media attracted huge attention from communication scholars. Study of perceived images of world nations remains a key area of research for international relations and international communication scholarship. The interest of images studies can be traced back to 1950s and 1960 
where general interest in psycho-attitudinal investigation led to political psychology of international relations (Feklyunina, 2010). According to recent investigative report published by BBC from EU Disinfor Lab, a Brussels-based NGO, there are coordinated network of 265 proIndian websites operating across 65 countries. These websites are meant to propagate fake propaganda about Pakistan aiming at distorting international image as well as to target decision makers in Europe against Pakistan(Carmichael \& Hussain, 2019). The political psychology of perceived images gained attention of international communication scholars and they worked to explore the relationships among the images of nations and their perceived importance in the mind of international audience (Herrmann \& Fischerkeller, 1995). As Alexander, Levin, and Henry (2005) emphasized image of foreign nations influence by the individuals social identity and social dominance. Segbers, Dyllick-Brenzinger, Hoffmann, and Mauersberger (2006)also stated that interaction has a social dimension. The relations between social groups are considered as important as diplomatic relation among states and governments.

Image theory is aimed to comprehend and develop and insight to the international relations. It is a model of 'strategic decision making' in that ideas about global actors are shaped into collective schemas, or perceptions, with thoughts and principles regarding the other's purposes, leadership, and primary characteristics. Image scholarships are meant to interpret the cognitive perceptions, the relations, images, and planned responses linked with the perceptions, stereotypes associated to other nations, explains reaction of a nation to or treatment towards other nation (Erişen, 2012).

International relations theory provides a set of assumptions for this psychological theory that propose perceives strategic associations can be considered as a meaning of supposed virtual power, nation, and the risk or opening that a subject believes another actor have(Herrmann, Voss, Schooler, \& Ciarrochi, 1997). Similarly, role of international media cannot be undermined in creating and shaping the images of global nations in this digital world. Media outlets are being consumed as major source of information and impression about politics across the globe (Williams, 2018).So the present paper aims to study and compare the images of India and Pakistan in international communication. 


\subsection{Indo-Pak Relations}

The partition of subcontinent in 1947 resulted in the emergence of two nation states i.e., Pakistan and India. The partition was done based on religion as Indian were considered as a Hindumajority nation while Pakistan was proposed by its father, Mr. Jinnah, to be the living paradise for Muslims to practice their lives according to the teachings of Islam (Tremblay, 2009). India and Pakistan are neighboring countries and both have many shared things including life style and geographical boundaries. At the same time, there is a dispute exist between both countries that is "Kashmir Dispute".

Kashmir dispute is considered as a bone of contention between two countries. Pakistan holds that as the partition was done on the basis of Muslim and Hindu majority, hence, the Kashmir should legitimately be a part Pakistan while India considers Kashmir as its part."“Pakistan has dependably mentioned that India direct the UN-requested plebiscite, an interest that India won't. India say Kashmir is authentically a piece of its land on the plea that lord decided to agree with India after its parcel. Another note worthy inspiration behind why India won't surrender Kashmir is help to different areas in India that requirement to sever from the Indian federation (Cohen, 2003)

The world is considered Kashmir as a nuclear flash point among two independent nations as both have been fought three times over Kashmir. In the last two decades the world has seen a lot of political and borders conflicts between two countries and violence which has one of the focal points of tense relations between the two. It is of great concern that despite several efforts of settling Kashmir issue have been made but no concrete outcome is received in this regard. Kashmir issue lead to severe tension among both the countries and it is one the biggest issue that hinders the normalization of bilateral relations. "Three full-fledged wars 1947, 1965,1971 and1999 were fought between two countries(Schofield, 2010).

Other than Kashmir, both nations often alleged one another for cross border terrorism. They are also hostile in economic cooperation. Pakistan alleged India that he is trying to sabotage ChinaPakistan Economic Corridor, which is a game changer program for Pakistan. Moreover, both nations have also closed their borders for trade. After the recent movement of India on Kashmir, revocation of Article 370 and 57, the relations has become more critical. Continuous ceasefire violations are being observed between two countries. 


\subsection{Twitter and International News Agencies}

Social and digital media has altogether changed the journalism creating and consuming patterns of the people (Griessner, 2012; Kulshmanov \& Ishanova, 2014). The world news agencies always keen and at their toes to report and disseminate of information (Ambrogi-Yanson, 2010; Bielsa, 2008; Dergisi, 1996; MacGregor, 2013; Ray \& Dutta, 2014; Stover \& Anawalt, 1983). With the inception of digital communication and sophisticated information technologies, the business of global news agencies like propagation and opinion making has been modified. Now, these agencies have an opportunity of direct contact with the audience as well as including features like multilingual texts, online news, multimediality, multi-channel availability. The increasing number of subscribers have changed qualitative characteristics significantly of these news agencies (Kulshmanov \& Ishanova, 2014). Present study will explore the activities of international news agencies about the coverage of Pakistan and India on interactive platform of Twitter.

Present study aimed to highlight the global news agencies coverage pattern of Pakistan and India on twitter. The study examined the sharing and liking of news tweets by their followers as well. As media's content is considered as the major part of Media's policy and they are playing a vital role in making and restructuring the public opinions, hence, it seems important to highlight and compare the media's coverage related to Pakistan and India especially under changing world political order and emergence of South Asia as hub of world trade. Moreover, the study also aimed

to comparatively analyze the coverage of four international news agencies about India and Pakistan.

\subsection{Objectives}

Followings are the major objectives of this research project:

1) To study the coverage of India and Pakistan in tweets of global news agencies.

2) To compare the portrayal of India and Pakistan in tweets of international news agencies.

3) To highlight the significant issues of India and Pakistan which are being discussed by International news agencies.

4) To compare the image of India and Pakistan in tweets of global news agencies.

5) To highlight the liking and sharing of India and Pakistan through the tweets.

\subsection{Research Questions}

Following research questions were formulated. 
RQ1: To what extent India and Pakistan are being covered in tweets international news agencies?

RQ2: How are India and Pakistan being covered in the given tweets of these news agencies?

RQ3: Which issues are being associated with Pakistan and India in tweets of news agencies?

RQ4: Is there any difference in image construction of India and Pakistan by global news agencies on Twitter?

RQ5: Is there any difference in liking and sharing of India and Pakistan by the users of these news agencies?

\section{Methodology}

We used social network analysis to study images of India and Pakistan. There are several studies found social network analysis as an effective methodology in international communication research (Barberá et al., 2015; Kick, McKinney, McDonald, \& Jorgenson, 2011; Kim \& Barnett, 1996). We have conducted content analysis and then data was prepared to matrix data. Descriptive and parametric tests were used to study and compare the image of India and Pakistan.

\subsection{Social Network Analysis}

Interpersonal organization investigation depends on a suspicion of the significance of connections among communicating units (Wasserman \& Faust, 1994). Socially applicable nodes associated by single or supplementary relations can be called as a social network."Network members, are the components that are connected by the relations whose patterns we analyze"(Marin \& Wellman, 2011). These units are most commonly persons, organizations, and in international context, states, nations etc. We are living in the age of highly interconnected network society. Network studies are important to understand power of networks. Therefore, social network analysis approaches seem helpful for identifying and comparing the images of India and Pakistan.

\subsection{Content Analysis}

Population of study was tweets of news agencies. Sample includes twitter accounts of four global news agencies; the Associated Press, Reuters, Agence France Presse and Xinhua of China. These news agencies completely dominate the international news industry (MacGregor, 2013; Stover \& Anawalt, 1983). Furthermore, it is argued that a message (tweet) and social interaction (retweet) among users placed Twitter better of other so news sources. The tweets were coded for the period 
of seven years from 1-1-2010 to 31-12-2016. Unit of analysis was the Tweet mentioning the name of India or Pakistan.

\subsection{Issues}

Based on previous literature, we selected and categorized news issues in 10 categories. These are; peace \& conflict, Human Rights, democracy \& politics, environment \& disasters, foreign relations, trade \& economy, science \& technology, sports \& culture, entertainment \& human interest, and defense \& strategic (Galtung \& Ruge, 1965; Kim \& Barnett, 1996; Ottosen, 2010; Sacco \& Bossio, 2015). (See annexure -1 for coding instructions and definitions).

\subsection{Replies, Favorites, Re-tweets and Shared Portrayal}

Due to quantitative analysis, we only calculated several retweets, responses, and preferences. We also calculated the shared portrayal of tweets. As it is noted that retweet amplify the information of world news agencies. This is claimed that positive tweet for a country by news agencies and subsequently the information is retweeted further by the followers then shared impression and shared representation will also add-on in positive course. On the other hand, if an international news organization investigation depends on a suspicion of the significance of connections among communicating units, so we have designed a method to map shared representation as follows: Shared representation $=$ Valence $\mathrm{x}(\#$ of Replies + \# of Retweets + \# of favorites $)$

Valence means the depiction of country-issue organization. Which is esteemed as $(+1,0$, and-1). Common depiction was determined by utilizing SPSS and putting factors above characterized equation.

\section{Findings}

Findings revealed significant variances in reporting of India and Pakistan in tweets of news organizations. India was tweeted more as compared to the Pakistan by international news agencies (Table 1). Moreover, AFP and Xinhua gave more coverage to India as compare to the AP and Reuters (Table 1). In this equation, we can shape an argument that Chinese news agency is covering India more, although China and Pakistan are considered as economic allies. On the other side, American and British news agencies are considering Pakistan more important as compare to the Francis and Chinese news agencies on twitter. Hence, findings support to answer RQ1 of study that India is being covered more in tweets of news organizations, however, AP and Reuters are giving more reporting to Pakistan. 
Table 1 Coverage of India and Pakistan 2010-16

\begin{tabular}{llrrr}
\hline & & \multicolumn{2}{c}{ Country Name } & \multicolumn{2}{c}{ Tota } \\
\cline { 3 - 4 } & & \multicolumn{2}{c}{ Paki } & \multicolumn{2}{c}{ Indi } & \\
stan & 723 & 813 & 153 \\
News-Agency & AFP & & & 6 \\
& & 415 & 400 & 815 \\
& AP & 502 & 460 & 962 \\
& Reuters & 152 & 286 & 438 \\
\hline Total & Xinhua & 1792 & 195 & 375 \\
& & & 9 & 1 \\
\hline
\end{tabular}

Note: $d f=3, X^{2}=41.02, p=.01$

Further it is found that there are significant variations in portrayal of Pakistan in the tweets (Table 2). AFP, AP and Reuters are covering Pakistan negatively. These agencies are propagating the negativity about Pakistan in their tweets. Chinese Xinhua is covering Pakistan positively (Table 2). Chinese agency is attempting to spread positivity about Pakistan. So, here we can argue that China is investing in Pakistan in number of economic ventures especially after materialization of the CPEC, hence, it is being covered positively in tweets of Xinhua.

Table 2. Portrayal of Pakistan in tweets 2010-16

\begin{tabular}{llrrrrr}
\hline & & \multicolumn{4}{c}{ News Agency } & Total \\
\cline { 3 - 6 } & & AFP & AP & Reuters & Xinhua & \\
\hline Portrayal of the & Negative & 433 & 335 & 302 & 36 & 1106 \\
Country & Neutral & 163 & 39 & 40 & 4 & 246 \\
& Positive & 127 & 41 & 160 & 112 & 440 \\
\hline Total & & 723 & 415 & 502 & 152 & 1792 \\
\hline
\end{tabular}

Note: $d f=6, X^{2}=344.03, p=.01$

On the other side, Table 3 reveals that India is also being covered negatively by the Franc and American news agencies in their tweets. However, Reuters coverage is almost balanced about India (Table 3). Interestingly, we find that on contrary to Pakistan, Xinhua is covering India negatively. In this way, we find answer RQ2 that AFP, AP and Reuters are covering Pakistan negatively, and Xinhua is covering Pakistan positively. On the other hand, AFP and AP also covering India negatively however coverage is balanced in case of Reuters and negative in case of Xinhua. 
Table 3 Portrayal of India in tweets: 2010-16

\begin{tabular}{llrrrrr}
\hline & & \multicolumn{3}{c}{ News-Agency } & \multirow{2}{*}{ Total } \\
\cline { 3 - 6 } & \multicolumn{1}{c}{ AFP } & AP & Reuters & Xinhua & \\
\hline Portrayal & Negative & 378 & 251 & 196 & 90 & 915 \\
& Neutral & 316 & 63 & 66 & 15 & 460 \\
& Positive & 119 & 86 & 198 & 181 & 584 \\
\hline Total & & 813 & 400 & 460 & 286 & 1959 \\
\hline
\end{tabular}

Note: $d f=6, X^{2}=393.52, p=.01$

We also find that international news agencies are discussing the issues of peace $\&$ conflicts, Human rights and foreign relations about Pakistan (Table 4). However, the peace and conflict issue is associated highly negative with Pakistan (Table 4). It indicates that Pakistan is covered negatively due to the presence of terrorism and other violent conflicts in Pakistan. Moreover, human rights violations are also being associated negatively with Pakistan. Coverage of foreign relations of Pakistan is almost balanced in the tweets.

Table 4 News Issues Associated with Pakistan in Tweets 2010-16

\begin{tabular}{llrrrr}
\hline & & \multicolumn{3}{c}{ Portrayal } & Total \\
\cline { 3 - 4 } & & Negative & Neutral & Positive & \\
\hline Determining & Peace \& Conflict & 491 & 20 & 87 & 598 \\
issue of News & Human Rights & 189 & 12 & 47 & 248 \\
Tweet & Democracy \& Politics & 120 & 25 & 49 & 194 \\
& Environment \& Disasters & 87 & 11 & 6 & 104 \\
& Foreign Relations & 104 & 5 & 110 & 219 \\
& Trade \& Economy & 12 & 4 & 32 & 48 \\
& Science \& Technology & 10 & 5 & 8 & 23 \\
& Sports \& Culture & 3 & 18 & 9 & 30 \\
& Entertainment \& Human & 9 & 146 & 36 & 191 \\
& Interest & & & & \\
& Defense \& Security & 81 & 0 & 56 & 137 \\
\hline Total & & 1106 & 246 & 440 & 1792 \\
\hline
\end{tabular}

On the other hand, Indian image is presented in diverse manner by international news agencies. India is highly associated with human rights issue in negative tone (Table 5). Therefore, it indicates that India is covered more due to the human rights violations in India, specifically due to the sexual abuse, gang rapes in India. India is also being associated with entertainment and human-interest stories. These stories tend to create neutral image of India and these were also 
presented in neutral tone by international news agencies (Table 5). Indian foreign relations are also being covered in tweets and this coverage is mostly positive in tone (Table 5). Hence, Table $4 \&$ 5 provide support to answer RQ3.

Table 5 News Issues Associated With India in Tweets 2010-16

\begin{tabular}{llrrrr}
\hline & & \multicolumn{2}{c}{ Portrayal } & Total \\
\cline { 3 - 4 } Determining issue & & Negative & Neutral & Positive & \\
\hline of News Tweet & Peace \& Conflict & 142 & 10 & 28 & 180 \\
& Human Rights & 356 & 6 & 36 & 398 \\
& Democracy \& Politics & 65 & 39 & 57 & 161 \\
& Environment \& Disasters & 160 & 20 & 20 & 200 \\
& Foreign Relations & 77 & 19 & 144 & 240 \\
& Trade \& Economy & 32 & 10 & 68 & 110 \\
& Science \& Technology & 30 & 13 & 74 & 117 \\
& Sports \& Culture & 19 & 37 & 42 & 98 \\
& Entertainment \& Human & 9 & 297 & 60 & 366 \\
& Interest & & & & \\
& Defense \& Security & 25 & 9 & 55 & 89 \\
\hline Total & & 915 & 460 & 584 & 1959 \\
\hline
\end{tabular}

Further this study highlights the image of Pakistan (Figure 1) and India (Figure 2) by using network analysis software of UCINET. Image theories of international relations argue that the state or individuals' identity should not be viewed in isolation (Alexander et al., 2005; Feklyunina, 2010). International audience creates the image of foreign nations or states according to the cognitive associations of issues and attributes of those nations (Erişen, 2012; Herrmann \& Fischerkeller, 1995)and media contribute significantly in providing, shaping and constructing those attributes and connotations (Alexander et al., 2005; Avraham \& Ketter, 2016; Giffard \& Rivenburgh, 2000; Kunczik, 2002; Williams, 2018). In this way, it is argued that media and international communication plays a central role in the image construction of world nations and states.

Our findings reveal that although the image of both nations in being constructed negatively by the international news agencies, yet Pakistan is highly negatively associated with conflicts and India is highly negative associated with human rights violations. Pakistan is also significantly related with human rights negatively. Pakistan's foreign relations are to some extent positively presented by international news agencies (Figure 1). India is highly negative associated with human rights and disasters. It has also significant tie with peace and conflict in negative tone 
(Figure 2). Overall findings address RQ4 of study and reveal that the image of both nations is being constructed negatively in tweets of global news organizations. Pakistan is associated negatively with peace and conflict and India is associated negatively with human rights violations.

Figure 1 Image of Pakistan in Tweets (2010-2016)

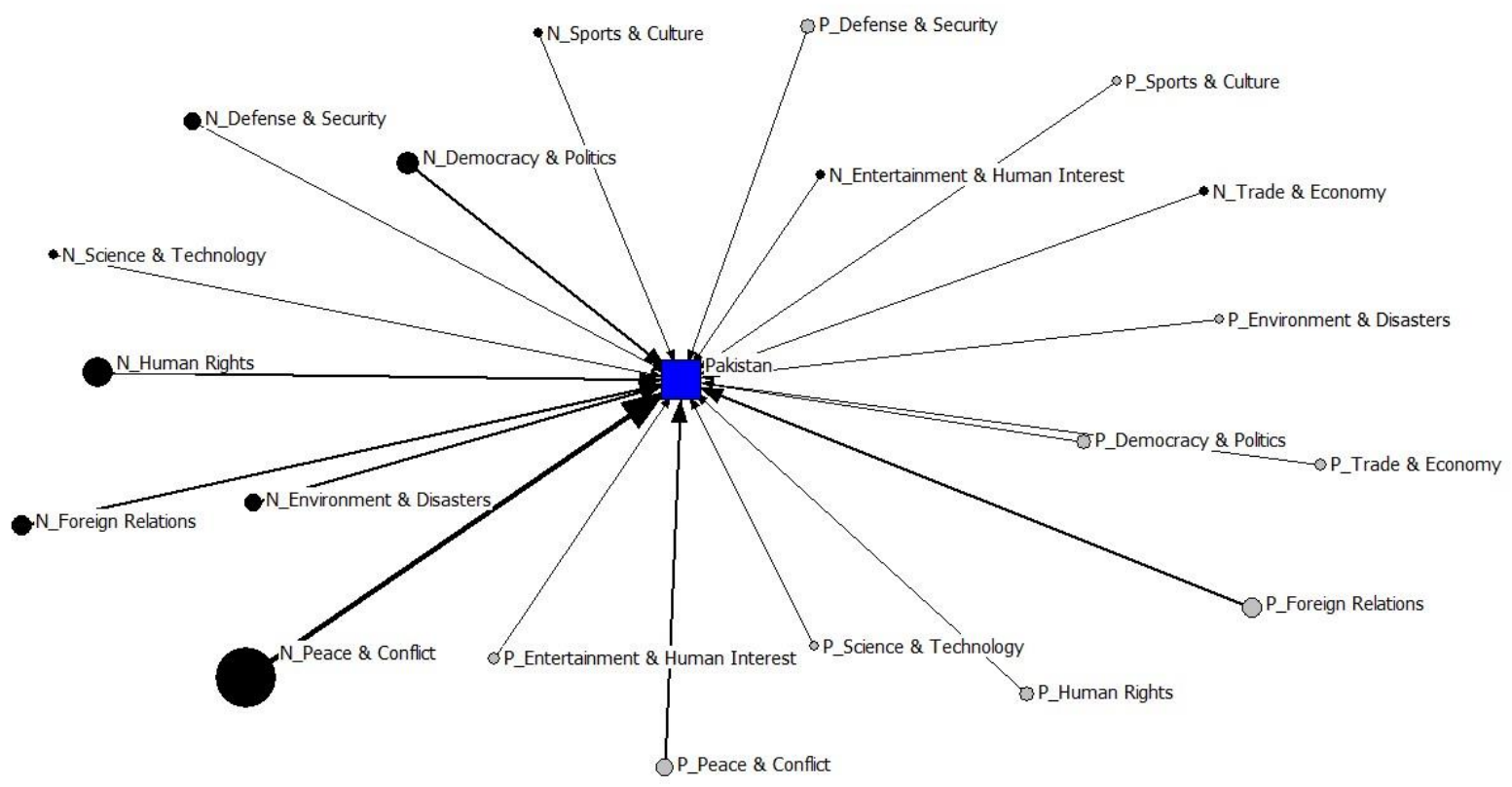

Note: Black circles represents negative associations and grey circles represent positive associations. Symbol size and lines thickness represents the frequency of elements

Figure 2 Image of India in Tweets (2010-2016)

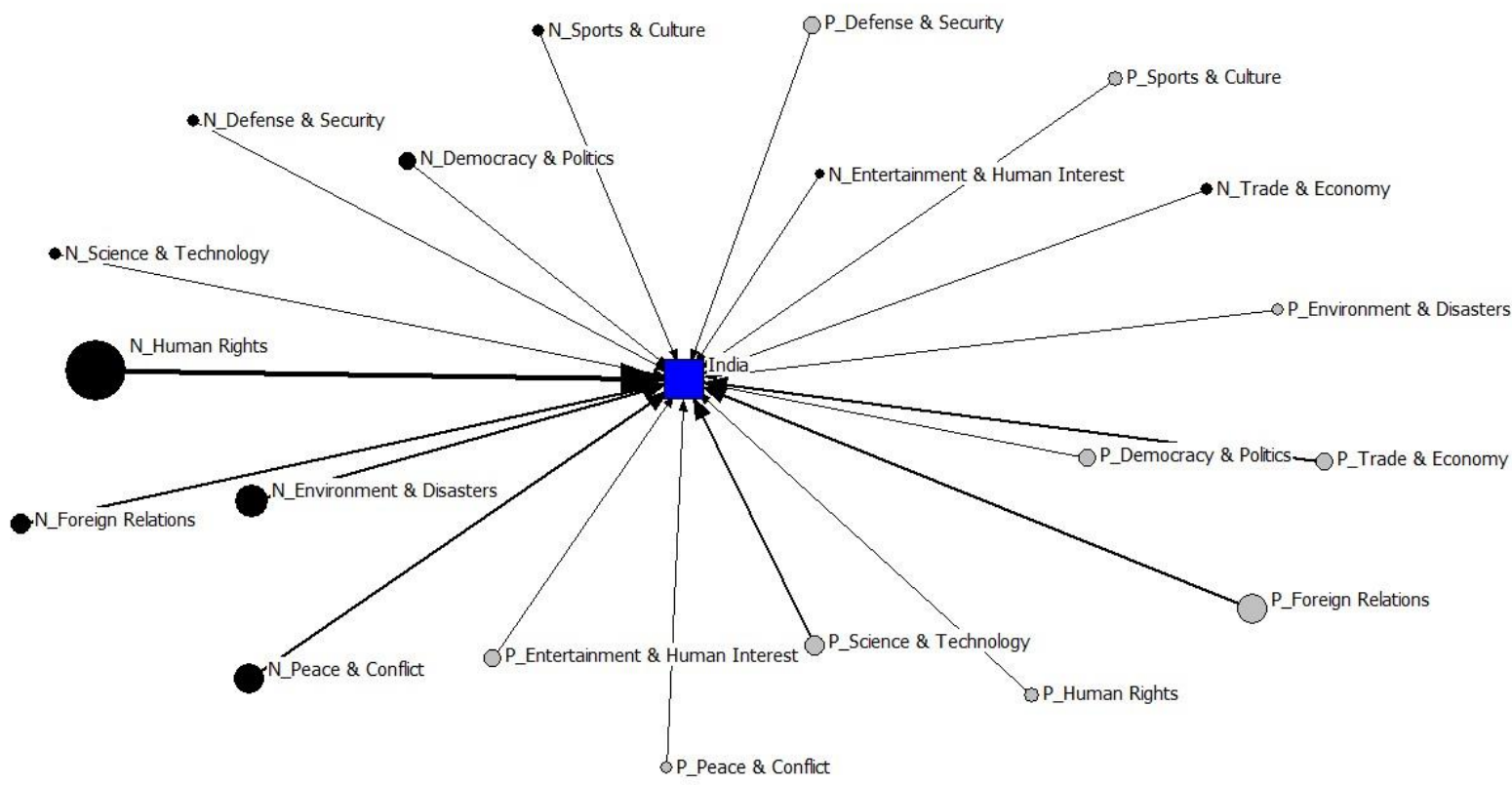


Note: Black circles represents negative associations and grey circles represent positive associations. Symbol size and lines thickness represents the frequency of elements

Another major objective of this study was to highlight and associate the liking and sharing of India and Pakistan in the tweets of news agencies. Because the interactive features of twitter cannot be underestimated for understanding the image of nations on twitter. We further observed highly substantial differences coverage and shared depiction of Pakistan and India (Table 6) and there are significant differences in liking of Pakistan and India (Table 6). Portrayal of Pakistan has been more negative as compared to India in tweets of news agencies. Similarly, not only global agencies but the followers are also sharing and propagating more negativity about Pakistan as compare to India. India is slightly more liked by the followers of international news agencies. In this way, current study found an evidence to conclude that international audience is also engaged on twitter for constructing and propagating online images of states and nations via the tweets.

Table 6 Differences in Retweets of News Agencies (2010-2016)

\begin{tabular}{|c|c|c|c|c|c|c|}
\hline & Country & $\mathrm{N}$ & M & SD & $\mathrm{T}$ & Sig. \\
\hline \multirow{2}{*}{$\begin{array}{l}\text { Portrayal of the } \\
\text { Country }\end{array}$} & Pakistan & 1792 & -.37 & .85 & \multirow[t]{2}{*}{-7.25} & \multirow[t]{2}{*}{$.000 * *$} \\
\hline & India & 1959 & -.16 & .85 & & \\
\hline \multirow{2}{*}{$\begin{array}{l}\text { Number of Tweet } \\
\text { Replies }\end{array}$} & Pakistan & 1792 & 4.28 & 18.13 & \multirow[t]{2}{*}{1.34} & \multirow[t]{2}{*}{.181} \\
\hline & India & 1959 & 3.48 & 18.64 & & \\
\hline \multirow[t]{2}{*}{ Number of Retweets } & Pakistan & 1792 & 77.07 & 123.53 & \multirow[t]{2}{*}{1.27} & \multirow[t]{2}{*}{.204} \\
\hline & India & 1958 & 72.48 & 96.51 & & \\
\hline \multirow[t]{2}{*}{ Number of Favorites } & Pakistan & 1792 & 28.29 & 53.56 & \multirow[t]{2}{*}{-1.92} & \multirow[t]{2}{*}{$.054 *$} \\
\hline & India & 1959 & 31.84 & 59.12 & & \\
\hline \multirow[t]{2}{*}{ Shared Portrayal } & Pakistan & 1792 & -48.62 & 188.97 & \multirow[t]{2}{*}{-5.85} & \multirow[t]{2}{*}{$.000 * *$} \\
\hline & India & 1958 & -14.68 & 166.04 & & \\
\hline
\end{tabular}

**differences are significant at .01 level

*Differences are significant at .05 level

\section{Conclusion}

We conducted this study to highlight and compare the image of two south Asian nuclear powers in online platform of twitter. We studied the coverage of India and Pakistan in tweets of four global news agencies; Associated Press, Agence France Press, Reuters and Xinhua. We observed that there are substantial variations in coverage, portrayal and sharing of Pakistan and India in tweets generated by news agencies. We found that India and Pakistan have been covered negatively in news tweets, but Pakistan's image is more negative as compare to India. Pakistan is 
highly associated with conflicts issues in negative tone and India is presented negatively due to human rights violations. Finally, it is concluded that not only these global news agencies, but followers are also sharing and propagating negativity more about Pakistan as compared to India.

\subsection{Recommendations}

Keeping in view the findings of the study, followings recommendations are being suggested.

1) Governments of both countries; India and Pakistan, should work to promote soft image of their countries by collaborating international news agencies.

2) Tourism and beauty of these countries should be encouraged to create soft stories about them.

3) Indigenous news agencies of India and Pakistan should be developed and digitalized for creating and disseminating soft image of both countries.

4) Media literacy and awareness about new media diplomacy should be created among the public specifically to the youth of India and Pakistan.

5) Access to modern information and communication technologies should be ensure at gross root level.

\section{References}

Alejandro, J. (2010). Journalism in the age of social media. Reuters Institute Fellowship Paper, University of Oxford, 2009-2010.

Alexander, M. G., Levin, S., \& Henry, P. J. (2005). Image theory, social identity, and social dominance: Structural characteristics and individual motives underlying international images. Political Psychology, 26(1), 27-45.

Ambrogi-Yanson, M. (2010). International news coverage online as presented by three news agencies. (Masters Unpublished dissertation), Rochester Institute of Technology, New York.

Avraham, E., \&Ketter, E. (2016). Factors Influencing the Media Image of Developing Countries. In E. Avraham \& E. Ketter (Eds.), Tourism Marketing for Developing Countries (pp. 25-37). UK: Palgrave Macmillan.

Barberá, P., Wang, N., Bonneau, R., Jost, J. T., Nagler, J., Tucker, J., \& González-Bailón, S. (2015). The Critical Periphery in the Growth of Social Protests. PloS one, 10(11), 115.

Bielsa, E. (2008). The pivotal role of news agencies in the context of globalization: a historical approach. Global Networks, 8(3), 347-366. 
Carmichael, F., \& Hussain, A. (2019, 19 December). Pro-Indian 'fake websites targeted decision makers in Europe'. Retrieved February 14, 2019, from https://www.bbc.com/news/world-asia-india-50749764

Castells, M. (2011). A Network Theory of Power. International Journal of Communication, 5, 773-787.

Cohen, S. P. (2003). The Jihadist Threat to Pakistan. The Washington Quarterly, 26(3), 5-25.

Dergisi, K. (1996). The International News Ageneies and the New World Information Order. Retrieved June 6, 2016, from http://dergipark.ulakbim.gov.tr/kurgu/article/viewFile/ $5000174901 / 5000157773$

Erişen, E. (2012). An Introduction to Political Psychology for International Relations Scholars. Perceptions: Journal of International Affairs, 17(3), 9-28.

Feklyunina, V. (2010). National images in international relations: Putin's Russia and the West. University of Glasgow.

Galtung, J., \&Ruge, M. H. (1965). The structure of foreign news: The presentation of the Congo, Cuba and Cyprus crises in four Norwegian newspapers. Journal of peace research, 2(1), 64-90.

Giffard, C. A., \&Rivenburgh, N. K. (2000). News agencies, national images, and global media events. Journalism \& Mass Communication Quarterly, 77(1), 8-21.

Griessner, C. (2012). News Agencies and Social Media: a relationship with a future? Reuters Institute for the Study of Journalism, 2012-2013.

Hansen, D., Shneiderman, B., \& Smith, M. A. (2010). Analyzing social media networks with NodeXL: Insights from a connected world. US: Morgan Kaufmann.

Herrmann, R. K., \& Fischerkeller, M. P. (1995). Beyond the enemy image and spiral model: cognitive-strategic research after the cold war. International Organization, 49(3), 415450 .

Herrmann, R. K., Voss, J. F., Schooler, T. Y., \&Ciarrochi, J. (1997). Images in international relations: An experimental test of cognitive schemata. International Studies Quarterly, 41(3), 403-433.

Kick, E. L., McKinney, L. A., McDonald, S., \& Jorgenson, A. (2011). A multiple-network analysis of the world system of nations, 1995-1999. In J. Scott \& P. J. Carrington (Eds.), Sage handbook of social network analysis (pp. 311-327). London: Sage Publications Ltd.

Kim, K., \& Barnett, G. A. (1996). The determinants of international news flow a network analysis. Communication Research, 23(3), 323-352.

Kulshmanov, K., \&Ishanova, A. (2014). News agencies in the era of globalization and new challenges of reality. Mediterranean Journal of Social Sciences, 5(19), 48-53.

Kunczik, M. (2002). Globalisation: News media, images of nations and the flow of international capital with special reference to the role of rating agencies. Journal of International Communication, 8(1), 39-79.

Li, X., \& Chitty, N. (2009). Reframing national image: A methodological framework. Conflict \& Communication, 8(2), 1-11. 
MacGregor, P. (2013). International news agencies: global eyes that never blink. In K. Fowler-Watt \& S. Allan (Eds.), Journalism (pp. 35-63). Bournemouth University, UK: Centre for Journalism \& Communication Research.

Marin, A., \& Wellman, B. (2011). Social Network Analysis: An Introduction. In J. Scott \& P. J. Carrington (Eds.), The Sage Handbook of Social Network Analysis (pp. 11-25). London: Sage Publications Ltd.

Ottosen, R. (2010). The war in Afghanistan and peace journalism in practice. Media, War \& Conflict, 3(3), 261-278.

Ray, A., \& Dutta, A. (2014). Information Imbalance: A Case Study of Print Media in India. International Journal of Scientific and Research Publications, 4(7), 1-5.

Sacco, V., \& Bossio, D. (2015). Using social media in the news reportage of War \& Conflict: Opportunities and Challenges. The Journal of Media Innovations, 2(1), 59-76.

Schofield, V. (2010). Kashmir in conflict: India, Pakistan and the unending war. London: Bloomsbury Publishing.

Segbers, K., Dyllick-Brenzinger, P., Hoffmann, K., \& Mauersberger, C. (2006). Global politics: how to use and apply theories of international relations. from https://www.ssoar.info/ssoar/bitstream/handle/document/43986/ssoar-2006segbers_et_alGlobal_politics_how_to_use.pdf?sequence=1\&isAllowed=y\&lnkname=sso ar-2006- segbers_et_al-Global_politics_how_to_use.pdf

Stover, W. A., \&Anawalt, H. (1983). Who Makes News? An Inquiry into the Creation and Controls of International Communications. Peace Research, 15(1), 15-23.

Tremblay, R. C. (2009). Kashmir's Secessionist Movement Resurfaces: Ethnic Identity, Community Competition, and the State. Asian Survey, 49(6), 924-950.

Wasserman, S., \& Faust, K. (1994). Social network analysis: Methods and applications. London: Cambridge university press.

Williams, M. C. (2018). International Relations in the Age of the Image. International Studies Quarterly, 62(4), 880-891. 
International Journal of Distance Education and E- Learning (IJDEEL) Volume VI- Issue I (December 2020)

Annexure - I: Coding Instructions and Definitions of Issues

ISSUES

\begin{tabular}{|c|c|c|}
\hline Sr. & Category & Key Terms \\
\hline 1 & Peace \& Conflict & $\begin{array}{l}\text { War, bombing, terrorist Attack, border conflicts, war killings, } \\
\text { war on terror, negotiations, Terror financing, Talibanization, } \\
\text { terror supporting, Negotiations, peace dialogues, statements } \\
\text { about peace, peace initiatives, Daaish, ISS, UNO Role, etc. }\end{array}$ \\
\hline 2 & Human Rights & $\begin{array}{l}\text { Social killings, feminity, women rights, poverty, health issues, } \\
\text { minority rights, injustice, third gender rights, children rights, } \\
\text { labor rights, Freedom of speech, etc. }\end{array}$ \\
\hline 3 & $\begin{array}{l}\text { Democracy \& } \\
\text { Politics }\end{array}$ & $\begin{array}{l}\text { Civil military conflicts, military coups, strikes, protests, civil } \\
\text { unrest, processions, elections, political rallies, laws, } \\
\text { legislation, bills, political leadership, electoral frauds, rigging, } \\
\text { political instability, etc. }\end{array}$ \\
\hline 4 & $\begin{array}{l}\text { Disasters \& } \\
\text { Environment }\end{array}$ & $\begin{array}{l}\text { Natural disasters, floods, earth quacks, fire, accidents, rains, } \\
\text { storms, tsunami, accidents, AIR crash, railway accidents, } \\
\text { carbon emission, pollution, etc. }\end{array}$ \\
\hline 5 & Foreign Relations & $\begin{array}{l}\text { Delegations, meetings, tours, statements, visits, agreements, } \\
\text { MOU, joint sessions, immigrations, etc. }\end{array}$ \\
\hline 6 & Trade \& Economy & $\begin{array}{l}\text { Trade and Economy, Trade agreements, trade exchanges, aid, } \\
\text { debt, crises, Inflation, IMF loans, unemployment, etc. }\end{array}$ \\
\hline 7 & $\begin{array}{l}\text { Science } \\
\text { Technology }\end{array}$ & $\begin{array}{l}\text { Scientific inventions, technological development, space } \\
\text { inventions, technological failure, scientific backwardness etc. }\end{array}$ \\
\hline 8 & Sports \& Culture & $\begin{array}{l}\text { Sports, Olympics, games, Easter, rituals, customs, World } \\
\text { cups, players, spot fixing, players drug addictions etc }\end{array}$ \\
\hline 9 & $\begin{array}{l}\text { Entertainment \& } \\
\text { Human Interest }\end{array}$ & $\begin{array}{l}\text { Personality, music, fashion, human interest, stars \& } \\
\text { celebrities, showbiz industry, films etc. }\end{array}$ \\
\hline 10 & $\begin{array}{l}\text { Defense } \\
\text { Security }\end{array}$ & $\begin{array}{l}\text { military collaborations, NATO alliance, military } \\
\text { development, missile development, defense budget \& } \\
\text { spending, chemical weapons, nuclear proliferation, NSG } \\
\text { (Nuclear supplier group), security lacks, insecurity, threats } \\
\text { etc. }\end{array}$ \\
\hline
\end{tabular}


International Journal of Distance Education and E- Learning (IJDEEL) Volume VI- Issue I (December 2020)

\section{VALENCE}

\section{Positive (+1)}

Positive image of the country concerned on human perception.

Neutral (0)

Neither positive nor negative image of the country concerned on human perception.

\section{Negative (-1)}

Negative image of the country concerned on human perception. 